\title{
GRAPHIC ASPECTS OF MOBILITY: FOLKLORISTIC-ETHNOLOGICAL DRAWINGS AS A STARTING POINT FOR DISCUSSING MOBILITY AND BORDERS
}

\author{
Kari Korolainen \\ Postdoctoral Researcher \\ Karelian Institute \\ University of Eastern Finland, Finland \\ kari.korolainen@uef.fi
}

\begin{abstract}
This paper discusses mobility within early twentieth-century folklore descriptions. Mobility is approached in terms of the culture of motion (Naukkarinen 2006), and in relation to borders and borderscapes (Brambilla 2015; Dell'Agnese \& Amilhat Szary 2015; Perera 2007; Rajaram \& Grundy-Warr 2007) as well as stretched environments (Povrzanović Frykman \& Humbracht 2013). The objective is to examine how mobility appears in former folklore contexts in case the viewpoint of drawing is concerned. Another aim is to combine art making with the analysis. The material is based on a folklore survey conducted by the Finnish Literature Society. The focus is on those survey responses that relate to eastern Finland and Finnish and Russian Karelia. Multimodal analysis is used for analyzing the relationship between the featured drawings and texts. Thus, the results demonstrate how the analysis, when accompanied by art making, could provide a point of departure for developing a multidisciplinary approach to discuss mobility and borders. The article illustrates how the materials, the analysis, and creative work intertwine in assessing presumptions and redirecting interpretations.
\end{abstract}

Keywords: archival materials, art making, border studies, borderscapes, cartoons, drawings, folklore studies, material culture, mobility, multimodal analysis

This paper discusses mobility that intertwines with folklore within early twentieth-century folklore descriptions. It is argued that these kinds of descriptions provide a productive point of departure for developing innovative methodologies for discussing folklore and mobility. Mobility is approached here, firstly, in terms of the culture of motion, following Naukkarinen, (2006: 18-19) who points out that many activities in contemporary lives relate to motion and movements. 
Urry (2008: 14), in turn, argues that while previous social research dealt with mobility in somewhat separate terms of work, migration, and communication, the present-day manner is to consider it more as an intertwined issue. Secondly, this article considers mobility in relation to borders, and the study leans on contemporary interdisciplinary border studies discussions, for instance, the formation processes of borders or the bordering stance (Yuval-Davies \& Wemyss $\&$ Cassidy 2018). The perspective of borderscapes is emphasized in order to take into consideration the socio-political contexts in which borders are lived and studied (see Brambilla 2015; Dell'Agnese \& Amilhat Szary 2015; Perera 2007; Rajaram \& Grundy-Warr 2007). This means that also textual, symbolic, temporal and other planes of borders are considered (see Jaago 2018; Schimanski 2006). Thirdly, mobility is addressed in terms of the continuity created within stretched locations, as, for instance, Povrzanović Frykman and Humbracht (2013) discuss in the context of their study of objects in migrant transnational lives (for material culture, see Tilley 2001; Glassie 1999).

Klein (2006: 23) mentions that "folklorists have incomparable opportunities to historicize the concerns of the present, to compare older and newer expressive forms and contexts with older ones". According to Noyes (2016: 13), one of the central tasks in folklore research is a "trying-out of interpretation". Thus, the work of folklorists resembles that of creative artists (ibid.: 12). Consequently, this paper is founded on an attempt to historicize mobility from the folklore stance, especially from the viewpoints of drawings and art making. ${ }^{1}$ The viewpoint of drawings is worth emphasizing since drawings comprise a somewhat untouched area in folklore studies in Finland (see Korolainen 2017, 2014). On the one hand, the drawing perspective may serve as a vehicle to approach discussions outside the scope of the artistic world (for line-making see Ingold 2007). On the other hand, in this paper drawing relates to art making, and thus, the discussion is loosely based on arts-based research (see Barone \& Eisner 2012; Cahnmann-Taylor 2008) and on drawing research where the relations between drawing and research are specifically considered (see Garner 2008; Drawing Research Network). ${ }^{2}$ It follows that the objective of this paper is to examine how mobile culture, mobility in relation to borders, as well as mobility in stretched material environments appear in former folklore contexts from the viewpoint of drawings. Another aim of the work is to combine art making with the analysis of folklore materials. 


\section{MATERIALS AND METHODS}

The research material for this paper is based on a folkloristic survey conducted by the Kansantieto periodical published by the Finnish Literature Society (SKS) in Finland from 1936 to 1939 . The inquiry was aimed at those citizens who were willing to "assist in rescuing our old archaic heritage" (Haavio 1936: 1). In many respects the Kansantieto survey followed a long line of Finnish folklore collecting (see Virtanen \& DuBois 2000: 25). In the 1930s (as also formerly), folklore collecting and research in Finland were based on a quest for the preservation of the disappearing Finnish folklore. In addition, this quest is part of the disciplinary history of Finnish folkloristics, and thus the relation of folkloristics to nationalistic state-building policies is regularly under critical discussion (see Pöysä 2018; Anttonen 2005; Wilson 1985).

The Kansantieto responses deal with various forms of folklore, such as ethnological issues, folktales, beliefs, customs, magic, as well as folk songs, games and plays. The research material used here is limited to those survey responses and submitted drawings that relate to eastern Finland and Finnish and Russian Karelia (i.e. borderlands). Hence, the material includes only 63 descriptions altogether. At the beginning of my study I did not use mobility or borders to define the research material, and it follows that the materials consider a variety of topics and folklore genres. However, I specifically discuss a body of 18 original descriptions for the reason that I used these descriptions as an inspiration for art making and they were therefore analyzed in detail. In terms of methodology, I lean on multimodal analysis which implies that the relationships between the featured drawings and texts are analyzed simultaneously. It is possible to specify how these drawings and texts are linked together, as well as how the compositions as a whole address the reader (see Kress 2010: 1-5, 79-83; Kress \& van Leeuwen 2006 [1996]; Korolainen 2014, 2017). Jewitt (2009: 16) points out that "[m]ultimodality can be used to build inventories of the semiotic resources (that is, the actions, materials and artefacts people communicate with) that modes make available to people in particular places and times". Moreover, it helps "people to see how a 'reality' comes to be represented" and offers "the potential to imagine it differently and to redesign it" (ibid.: 23). Hence, in this study, multimodal research offers information for constructing analytical inventories of people's uses of texts and drawings in the materialhistorical context of early twentieth-century folklore collecting, as well as for capturing different representations of mobilities, both now and then. 


\section{DRAWINGS WITHIN FOLKLORE MATERIALS}

The word 'drawing' refers here to hand-made visual representations that are based on lines and made with a pen (ink) or pencil (see Lukkarinen 2015: 24-28). Ink and pencil are the main techniques used for drawing within the materials (see Fig. 1). As a rule, the drawings are fairly small in size, and colors and shading are rarely used. Furthermore, these kinds of folkloristic drawings are usually accompanied by folklore texts.

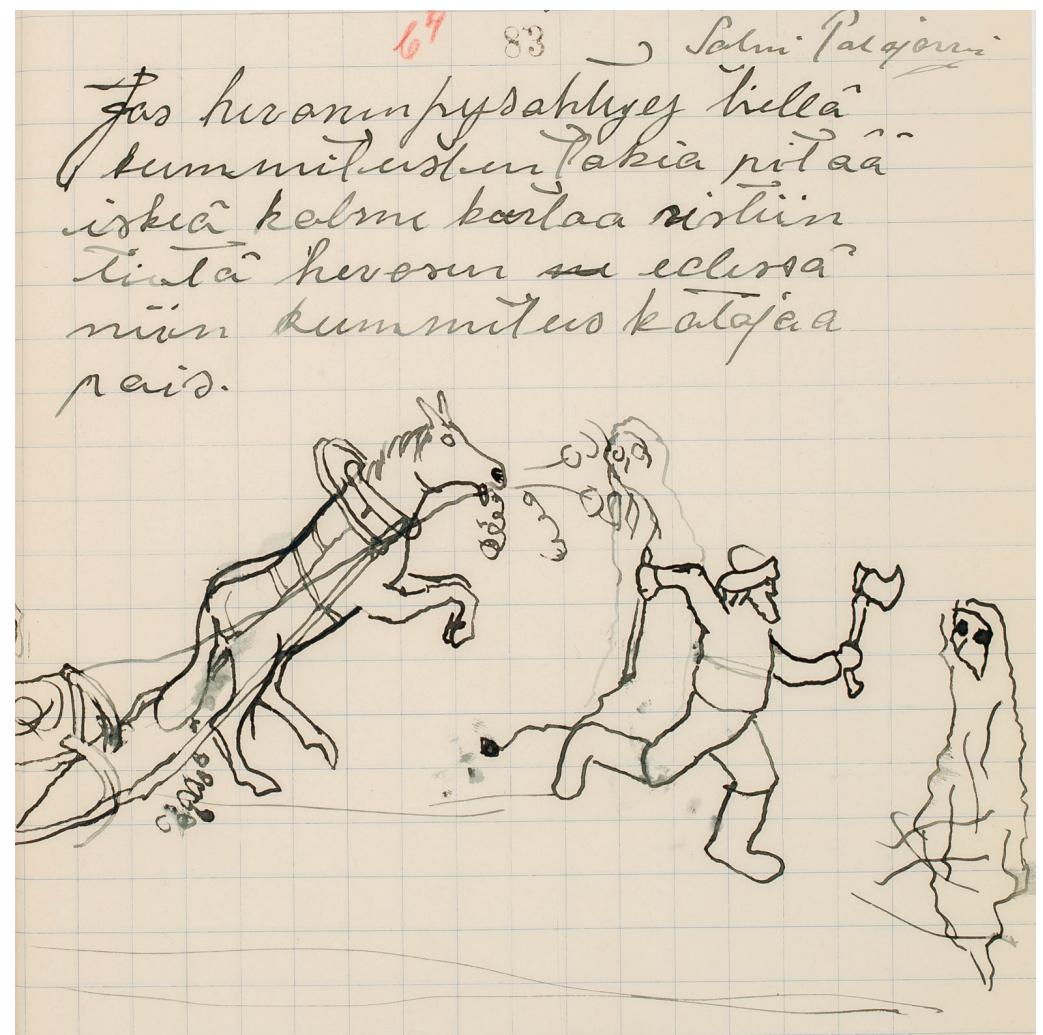

Figure 1. A description of how to use magic for exorcising ghosts. SKS KRA. Hämäläinen, Martti KT 123:83. $1936^{3}$.

When considering the subjects, numerous drawings deal with activities or incidents such as in the example above. This particular description concerns a situation in which, if ghosts pull over a horse-drawn vehicle, one should hit 
the path with an axe three times crosswise in order to get rid of them. When the document is examined from a multimodal analysis stance, it can be noticed that the description does not include much textual or visual contextualization (see Kress \& van Leeuwen 2006 [1996]: 161-162). Despite the fact that the visual representation is moderately simplified, the drawing still includes some visual details. For instance, the anatomy of the horse, the person's clothes and the details of the wagon are portrayed. Furthermore, it can be noticed that the information value is founded on an arrangement in which the text above (as configured in the original material) serves as an Ideal element and the drawing underneath the text as a Real element (ibid.: 179-185). ${ }^{4}$ The drawing stands out from the document clearly, and, accordingly, the salience of the drawing is high. In addition, the modality or the reliability of message is worth considering because the ghosts discussed are depicted in the drawing (ibid.: 155-156). ${ }^{5}$

A few other examples of activities captured within the drawings are worth mentioning, even if only briefly. For instance, one drawing portrays a woman swinging a cradle, and illustrates an account of the lyrics of a folk (cradle) song (SKS KRA. Hämäläinen, Martti KT 123:80. 1936). Another account of a folk song illustrates daily chores being carried out by the animals mentioned in the song. For instance, in one of these drawings a crow sweeps the floor with a broom (SKS KRA. Karjalainen, Kauko KT 73:131. 1937). Occasionally, the activity is pictured by means of showing a person's position, such as the legsapart position for conducting dairy farming magic, a belief linking to the position of a foot (SKS KRA. Pulliainen, Liina KT 117:27. 1936; KT 257:288. 1948), the starting position in a folk game (SKS KRA. Takala, Eevi KT 160:69. 1938), or the phases of throwing straws onto the ground when telling the fortune (SKS KRA. Kuosmanen, H. E. KT 149:29. 1936).

A great majority of the drawings depict solely material objects such as a thing or stuff (see Miller 2010). The depicted objects are commonly tools, utility articles, dishes, garments or their details, and they relate somehow to the matters described. The page featured in Figure 2 presents drawings of a sickle and a scythe. Other similar drawings that focus namely on objects depict, for instance, a bird trap (and its parts) (SKS KRA. Härkönen, Olavi KT 145:10-11. 1936), a stick that serves as a gaming instrument (SKS KRA. Mutanen, Aari KT 241:142. 1941) or a folded scarf (SKS KRA. Pulliainen, Liina KT 257:230. 1948). In these cases, the environment in which the object is used is not regularly portrayed in the drawing. In multimodal terms, the drawings are abstracted (no background, shading, etc.), and their salience is high because they clearly stand out from the document and thus attract the reader (see Kress \& van Leeuwen 2006 [1996]: 177). Here too, it is not difficult to distinguish the objects amidst the text. Contrastingly, however, in the first example, the axe is depicted in 
the environment of its use, and for this reason it is possible to conclude that the focus is not so much on the object itself but rather on the implementation of the magic and on the situation in general.

In addition to the drawings showing material objects, there are also numerous variations of technical drawings. These include drawings that depict buildings, such as plans of a single building (SKS KRA. Pulliainen, Liina KT 257:145. 1948; SKS KRA. Sormunen, K. A. KT 160:19. 1938), plan drawings of barnyards (see Fig. 5) or maps (SKS KRA. Tanskanen, Pekka KT 161:11. 1938). Furthermore, there are technical drawings that include specifications of the parts or measurements of an object, as seen in the case of a rack for drying hay

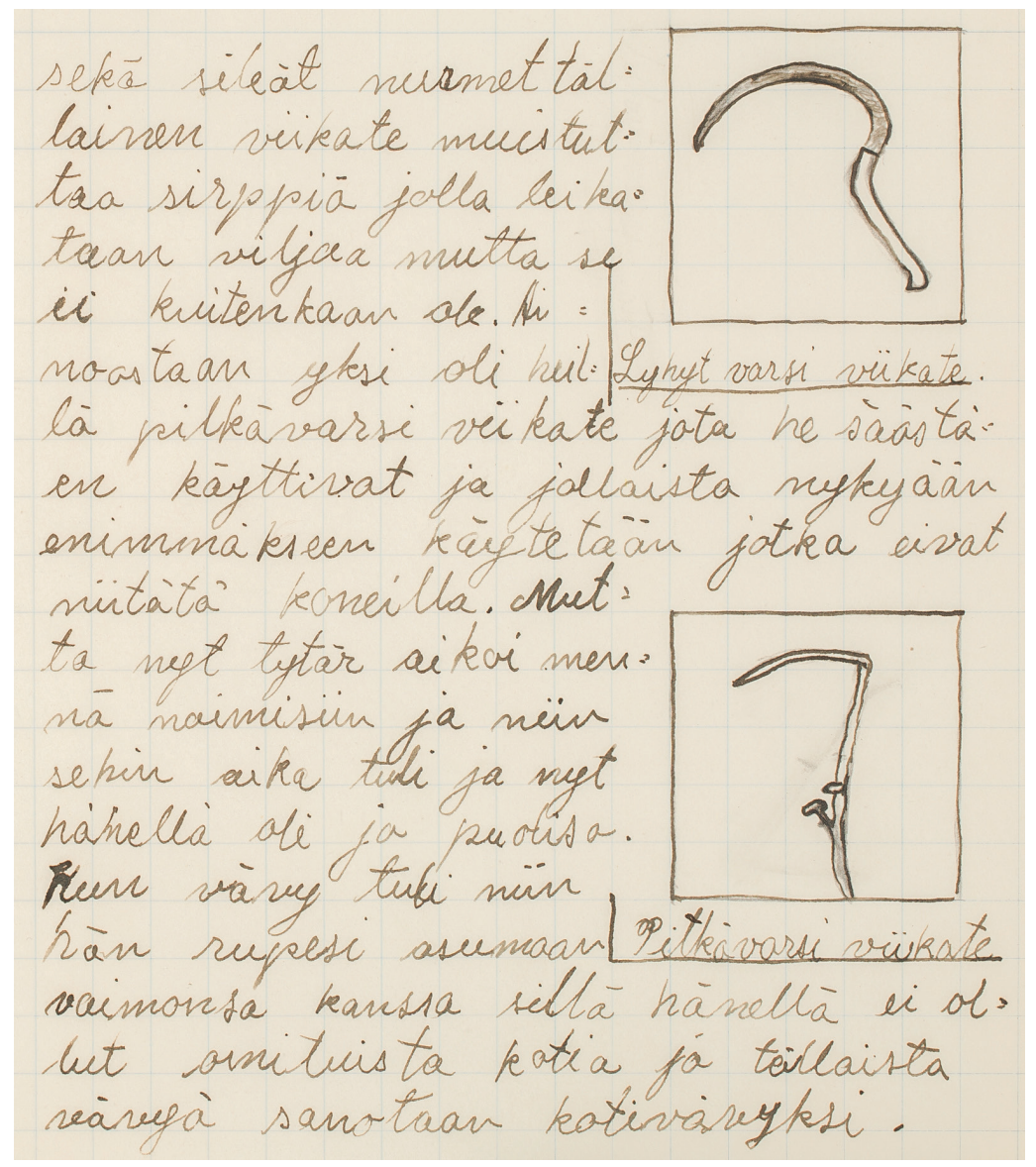

Figure 2. Two drawings portraying objects. SKS KRA. Jeskanen, Antrei KT 126:24. $1936^{6}$. 
(see Fig. 4), or in the sectional drawing of a trap (SKS KRA. Pätynen, O. V. KT 80:12. 1937). Also, diagrams were used for specifying locations, proportions, and other details. For example, in one case, the diagram shows a circle-shaped track that was trodden on the snowy ground in the course of a folk game (SKS KRA. Puranen, Kauko KT 100:38. 1936). Other diagrams portray the location of the stone that served as a playing tool (SKS KRA. Mikkola, Anna KT 254:28. 1949) or how trees by the road were bound together in the course of conducting dairy-farming magic aimed to track down stray cattle (SKS KRA. Leinonen, Janne KT 150:5. 1938).

Occasionally, the drawings deal with visual or drawing folklore where the act of drawing constitutes a crucial part of the folklore itself, for example, when folk plays include the act of drawing used in tandem with storytelling (SKS KRA. Takala, Eevi KT 160:71. 1938; Puumalainen, Martta KT 158:56. 1937). Sometimes the descriptions address symbols and other graphic visualizations, and regularly star-shaped symbols are seen that relate to magical customs (SKS KRA. Hakkarainen, Samuel KT 107:23. 1937; SKS KRA. Toijonen, Juho KT 120:89. 1936).

\section{BEING ON THE ROAD}

As mentioned earlier, mundane conceptions of mobility and borders were used at the outset of the analysis for itemizing the materials. Accordingly, mobility can be conceptualized in forms of mobile occupations and identities, such as in the case of travelling salespersons and their gear (see Fig. 3). Mobility links to the mobile aspects of farming and keeping cattle, for example, where herding takes place outside the barnyards located closest to the home farm (SKS KRA. Pulliainen, Liina KT 117:27. 1936), or when the description tells how people used to deliver cargo during winter time, while working on the farm in the summer (SKS KRA. Jeskanen, Antrei KT 126:24. 1936). Another account of hay-drying equipment illustrates an apparatus used in remote meadows (see Fig. 4). In this context, mobility refers to the ability to move (see OED 2019); however, mobility is also manifested within a more playful context, namely that of folk games and plays (SKS KRA. Puumalainen, Martta KT 158:56. 1937; SKS KRA. Takala, Eevi KT 160:71 and 72. 1938).

In Figure 1, the description addresses travelling to the church; therefore, mobility is expressed in a sense of 'being on the road'. However, the ability to move is challenged by the presence of ghosts. In multimodal terms, the drawing consists of actors, such as a person, a horse, and a ghost, and the transaction between these actors in this case involves the interruption of the journey (see 
Kress \& van Leeuwen 2006 [1996]: 45-75). The interaction (ibid.: 114) between the document and the reader is founded on somewhat subjective orientation due to the fact that the reader observes the events from a side angle, almost as if it was observed from the roadside.

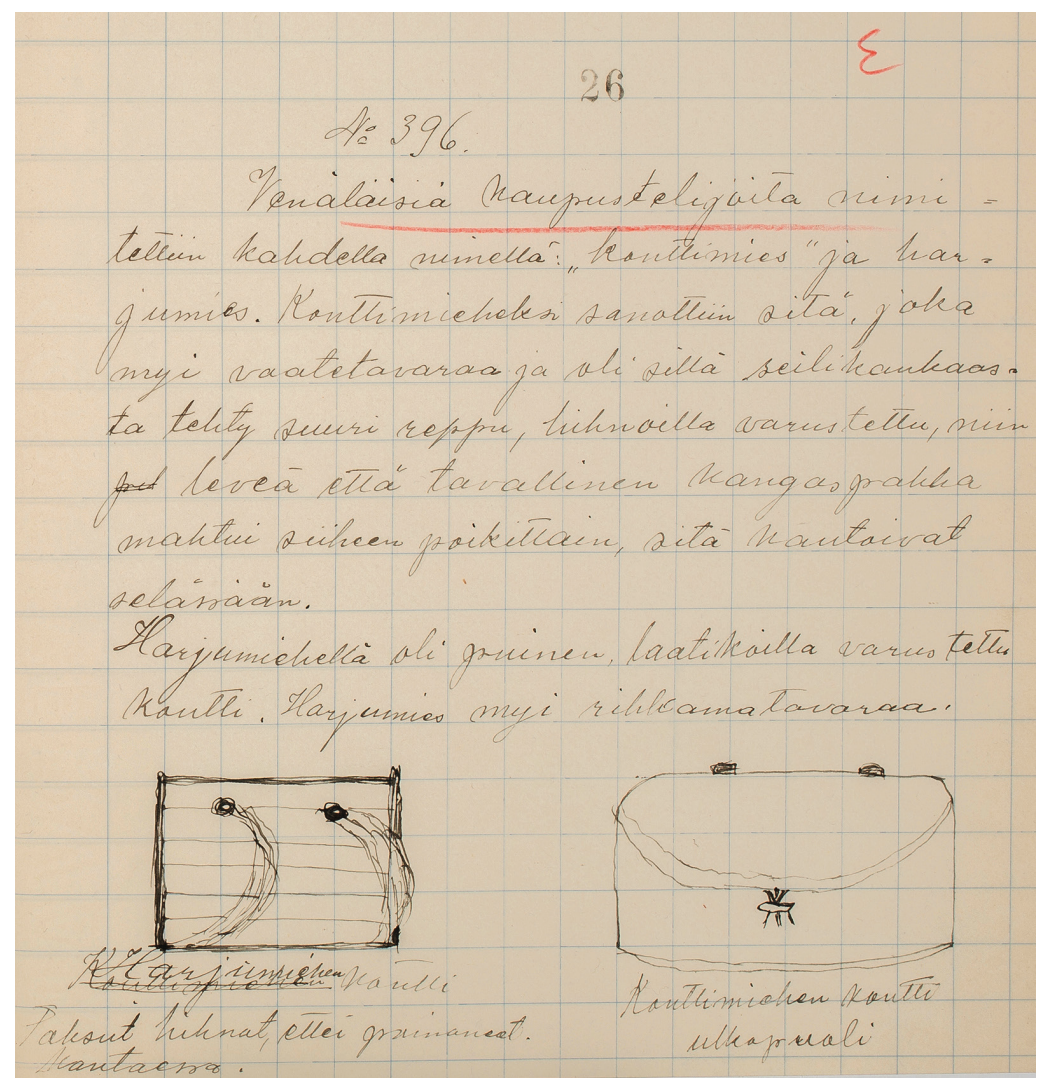

Figure 3. A description of suitcases. SKS KRA. Hoikkala, Gunilla KT 107:26. 1937.

Figure 3 shows the first page of a description where the writer explains, for instance, what kinds of merchandise (objects, accessories, materials, and substances) a travelling Russian salesperson may have carried in the borderlands of Finland and Russia. ${ }^{7}$ In this case, mobility is again exemplified in terms of 'being on the road', as well as in terms of mobile occupations, especially from a salesperson's perspective. In terms of multimodal analysis, there is an 
analytical structure to be seen in that the suitcases featured in the drawing serve as possessive attributes of the actors (the salespersons) involved (Kress \& van Leeuwen 2006 [1996]: 107). The frontal angle and the absence of background emphasizes the appearance of the suitcases, yet the text is an idealized (Ideal) or generalized account of the activities of the salespersons, while the drawings (Real) show specific items belonging to these persons. Thus, the role of the original drawings is to show the differences between these items. In addition, the writer represents the practices of the merchants as common and everyday practices around that time.

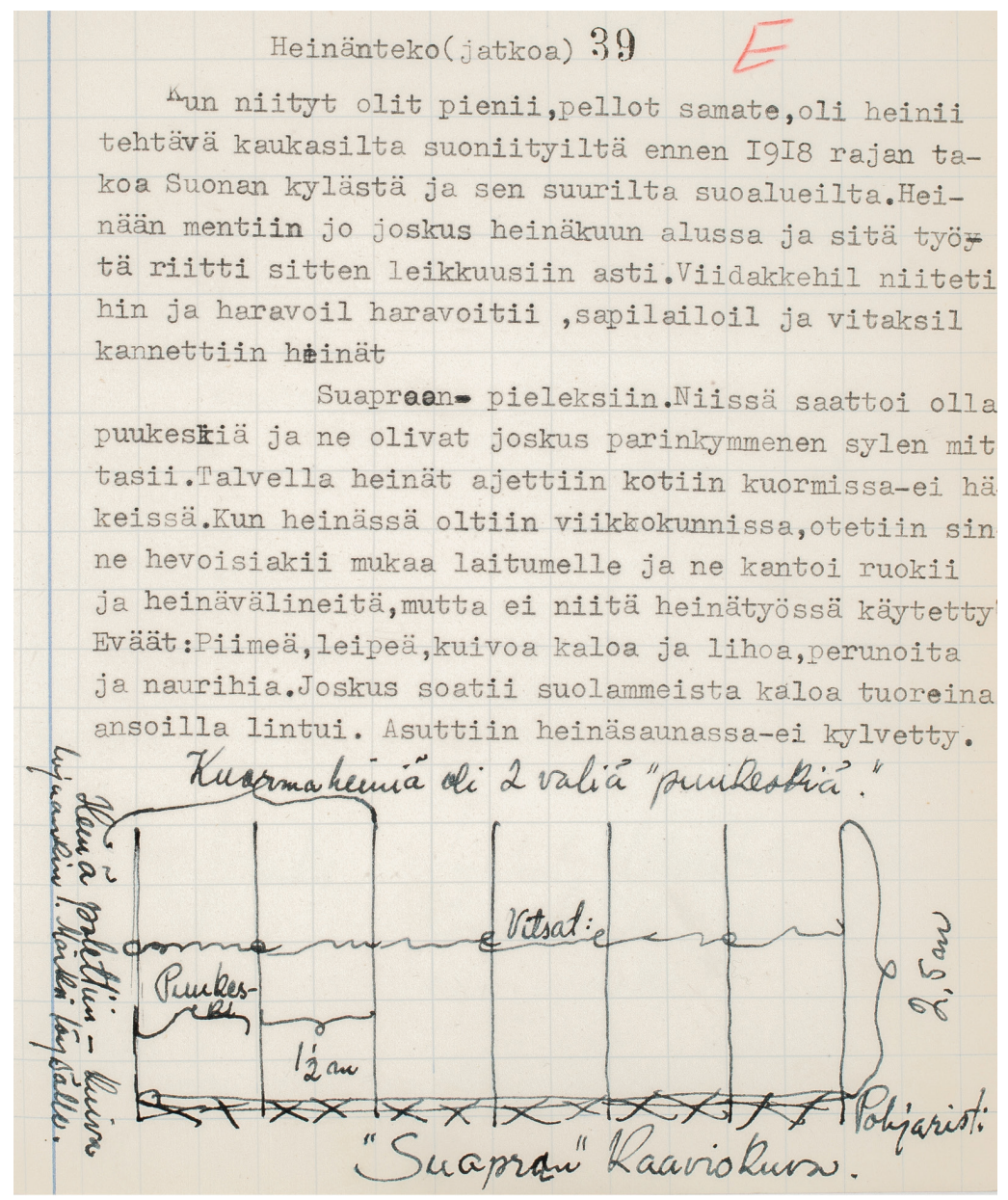

Figure 4. Description of a hay-drying structure called suapra. SKS KRA. Korhonen, M. KT 287:39. 1957. 
The description of a suapra includes an ethnological account of the use and structure of a hay-drying construction that was used in remote peatland meadows. The description as a whole constitutes a broad account concerning different work customs and divided into monthly periods described in the text. The idea of mobility is specified as the text (Fig. 4) explains that "[t]he meadows, as well as the fields, were small in size, therefore, hay was cut in remote peatland meadows prior to 1918, and also the ones behind the border [between Finland and Russia]". The drawing depicts a technical representation of a hay-drying apparatus. In terms of multimodal analysis, the object (a suapra) is the carrier. The interaction between the reader and the document provides a somewhat impersonal (rather than an intimate or social) account on the topic. Moreover, the picture depicts the object from a distance and the purpose of the drawing is to illustrate the structure of the object. Mobility and borders are brought up in turn as background information. Accordingly, while the overall focus is ethnological, the description presents details concerning the geopolitical situation, for instance, the Russo-Finnish border as a central feature that links to mobility.

\section{MOBILITY IN RELATION TO BORDERS}

In a general sense, borders were approached at the outset of the study, similar to the notion of mobility. Here, the preliminary notion of border relates to that of boundaries as "material and metaphorical spatializations of difference" (Morehouse 2004: 20). Accordingly, temporal, spatial, and other symbolic borders are seen as more common than actual geographical state borders. When considered in retrospect, the itemization of the materials at least partly follows a classification introduced by Schimanski (2006) in the context of "border poetics" (see Jaago 2018). Schimanski (2006: 53-57) distinguishes five planes of borders: textual, symbolic, temporal, epistemological, and topographical borders. The symbolic, temporal, and topographical planes of borders are especially distinguishable here, and are therefore further discussed below. ${ }^{8}$

The example with the suitcases concerns (among other things) the tightening of official supervision as well as its impact on commerce around the turn of the nineteenth century (see Jussila 2004: 453-458). Borders are manifested in a symbolic sense due to the fact that the nationality or Russian origin of the salespersons was emphasized in the text, although at the time of the events described, Finland was a grand duchy of the Russian Empire. However, other examples concerning the symbolic borders can be seen within the research material. For instance, one example described the manner in which a scarf was 
tied as symbolizing the wearer's marital status and thus brought up the issue of marital status borders or differences, and a second example described how the method of cutting bread could illustrate the borders or margins of poverty (SKS KRA. Pulliainen, Liina KT 257:230 and 261. 1948).

Only nine cases within the research material explicitly address geographical or state borders. However, spatial borders are considered more generally and there are numerous examples to be seen. Schimanski (2006: 56-57) speaks of micro-scale and macro-scale topographical borders. This distinction is also applicable here. When macro-scale or state borders are concerned, the borders of Finland (or Sweden-Finland) and Russia are emphasized, which is not surprising given the geographical outlining of the materials (see Fig. 3 and 4). Additionally, a few examples concern the borders between the provinces or regions of Finland (SKS KRA. Viinikainen, Kalle KT 85:40. 1938; SKS KRA. Tanskanen, Pekka KT 161:11. 1938; SKS KRA. Pulliainen, Liina KT 257:145. 1948). The majority of other topographical small-scale borders refer to spatial borders between the home and its surroundings, and these can be considered from the viewpoint of stretched environments. ${ }^{9}$

\section{MOBILITY AND STRETCHED MATERIAL ENVIRONMENTS}

Figure 5 shows a plan of a farmyard and originates from a survey response which concerns various local history matters. This one-page plan is located at the end of an extensive text; however, there is a short accompanying text on the right lower corner of the page, which reads: "NB. The house was cut in two while dividing the farm. The dashed line points to the cutting-line. The other half is located on the neighbor's plot." The cutting line in the figure runs across the building on the left. In this context, mobility is thinkable in terms of a stretched environment since, according to the text, the other half of the house was physically moved into another location.

The next example (Fig. 6) is related to a description that deals with a personal joke. The text concerns a situation in which the material surroundings are stretched. The text reveals how a poor man built a house, and, as he did not include a porch, the villagers started to joke that, accordingly, the whole village served as this man's porch. ${ }^{10}$

The material includes a similar kind of story of a man who had to keep cows outdoors in an 'alley' (kuja) behind the unfinished cowshed. As he had not yet finished the cowshed, the man considered the whole forest as being his cowshed (SKS KRA. Pulliainen, Liina KT 257:145. 1948). In multimodal terms, plans 


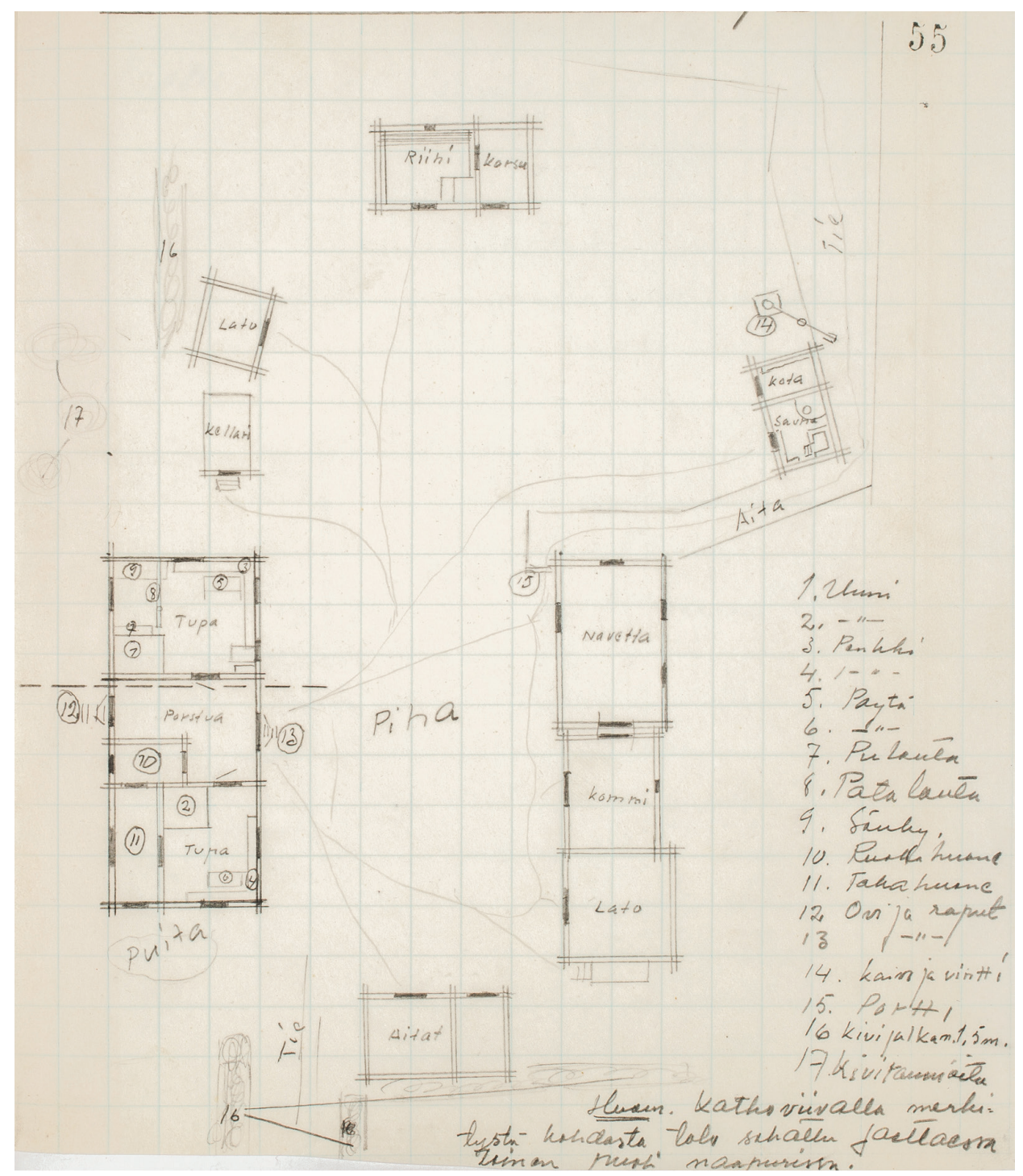

Figure 5. Plan of a farmyard.

SKS KRA. Simonen, Vilho KT 260:55. 1948.

are analytical images in that a top-down angle is used. According to this line of thinking, the attitude in plans towards the reader is objective (see Kress \& van Leeuwen 2006 [1996]: 144-145), and in the above cases, the attitude is objective in a sense that the reader observes the lives of the villagers from above. This orientation was amplified especially within the description in Figure 5, 


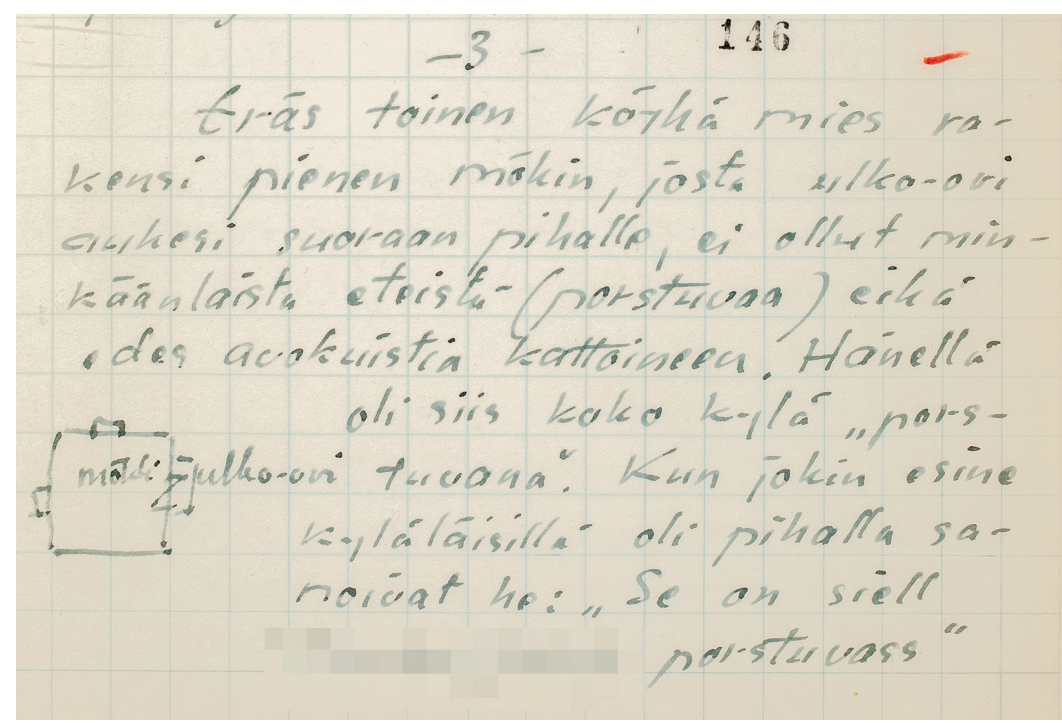

Figure 6. A house without a porch. SKS KRA. Pulliainen, Liina KT 257:146. 1948.

because the relationship between the plan and the accompanying description is loose. The jokes portrayed in the examples of the 'village as a porch' and of the 'forest as a cowshed' are founded on a similar logic, and in multimodal terms confusion arises when it is not clear what is the possessive attribute of which carrier. In these tellings, the porch is not seen as a possessive attribute of a house (as it might seem at first glance), but rather as an attribute of the village. Similarly, the alley is not represented as a possessive attribute of a cowshed, but rather as one of the forests. The comparison of these examples also illustrates how similar visual techniques (i.e. plans) can be used for different purposes, for example, for illustrating local/family history or personal jokes, but both from a distance.

\section{PERCEPTIBILITY OF MOBILITY: AN ARTISTIC VIEWPOINT}

The drawings above mostly focus on objects, activities, and technical details, or they are multiple mixed drawings. The above discussion focuses on the types of drawings found within the selected folklore materials, and on how mobility and borders are manifested by and within them. During the analysis, I made artistic drawings myself in order to ponder the topic and materials from 
a different point of view. ${ }^{11}$ Figure 7 presents a drawing that links to mobility in a general way and addresses it playfully. In this example, one can see how borders govern contemporary lives, and how games in particular are played within associated borderlines. As such, it becomes possible to consider folk games in terms of their visual borders, for instance, when the playing area is drawn on the ground. It shows the concept of the dual characteristics of borders, which was previously emphasized when I discussed boundaries (see Morehouse 2004). Cartoons like this help us make visual notes regarding the thoughts that form within a research process.

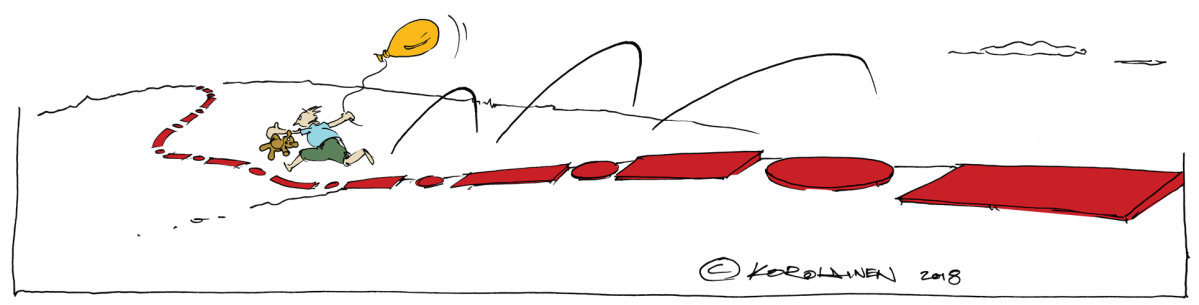

Figure 7. An untitled cartoon. Kari Korolainen 2018.

Figure 8 in turn presents a cartoon which relates more closely to the research conception of border aesthetics. Rosello and Wolfe (2017: 5) consider aesthetics in a sense that "[i]t participates in the apprehension of a border through sensory perceptions". Elsewhere, the concept of mobile aesthetics is also discussed, and Naukkarinen (2006: 29-34) links mobile aesthetics to environmental aesthetics and discusses how aesthetics relates to mobility more generally. Accordingly, it is possible to consider the cartoon in Figure 8 from a stance of visualization, and as Ursyn (2008: 174) points out, "[b]eing creative requires a capacity for abstract thinking and drawing can provide an excellent tool to support this". In the above cartoon, while the border is not perceptible, it is still emphasized by depicting the pale character in a forward-leaning position. Moreover, the contours of the clothes suggest that the person is pressing against an invisible wire. Tension can be seen between mobility and stillness since the pale character (a ghost perhaps) is motionless, while the other, crimson character, in flesh and blood, is passing by. A question that this image raises is: if the border is somehow imperceptible, does it necessarily indicate that it is un-representable? 


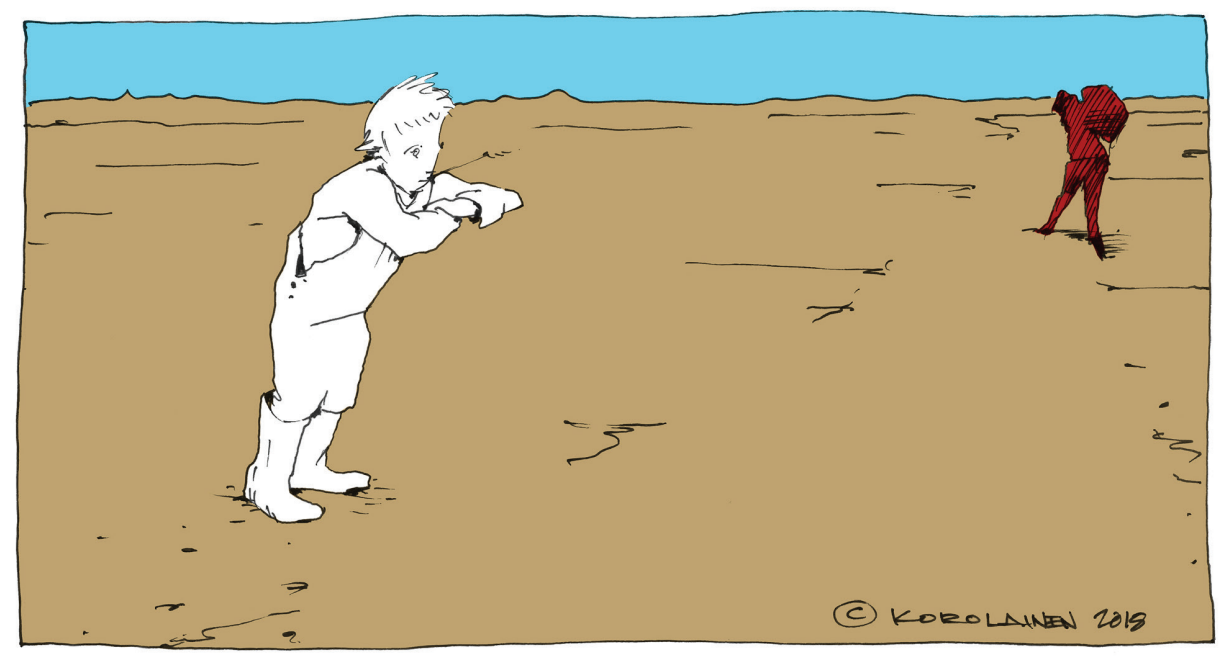

Figure 8. An untitled cartoon. Kari Korolainen 2018.

\section{CONCLUSIONS}

The analytical phases discussed here illustrate different working orientations rather than separated work procedures that follow each other. In the first stage, the results indicate that there are several similarities between these kinds of folklore drawings as far as their features are concerned. In spite of this, however, the drawings are not uniform and they serve multiple descriptive purposes. Some drawings are more illustrative, without a specific role within the description, while others explicate the technical details or other features faithfully. Often, they serve to emphasize specific aspects of larger wholes, or to concretize abstract issues. Especially, they seem to exemplify topics in cases where the linked texts are idealized, or otherwise operate on a general level. Thus, these drawings should not be considered as mere illustrations, as it can be clearly seen that the drawings intertwine with the descriptions in detail and in various issues of style. In multimodal terms, the variety of semiotic resources used here indicates the innovative orientation people have adopted in their folklore survey responses.

The second phase of this research analysis consisted of examining mobility and borders through the lenses of these drawings. The above analysis shows 
that it is possible to detect examples within the folkloristic descriptions that relate to different aspects of mobility. This is true in spite of the fact that mobility matters were not a focal point in the original Kansantieto survey. Still, people addressed issues that relate to mobility, and hence it can be argued that mobility and borders are diversely represented in a folkloristic context, especially when they are concerned with people and viewed from a folklore collecting perspective.

The third phase of the analysis was founded on art making and drawing. The aim was to ponder what kinds of imaginative dimensions mobility and borders might have in this context. Firstly, I emphasized how mobility and borders can be recognized and how they are depictable. The results suggest that this kind of approach is apt for pondering these research conceptions theoretically. Moreover, the approach raised the question of how the issue of the imperceptibility of borders or the stretched environment can be suitably depicted. Secondly, the act of my drawing in the role of a researcher served as an instrument for concretizing this imaginative work, mainly due to the fact that my cartoons are based on a representational cartoon (art) tradition. It follows that I was bound by representational visual conventions that, accordingly, directed the thought process. For example, the situation of cutting a house in two is, generally speaking, not that difficult to imagine visually. However, a whole village being considered as someone's porch is more difficult to imagine and visualize. The representational visual practices within cartoon making are not so much guided by research methodologies, and, instead, naturally comprise a different technique for posing questions when compared to, say, reading or writing. I emphasized representational drawings; hence, there are a variety of practical questions that arise when following this orientation, such as how to depict clothes, the desert, barbed wire, etc. Thus, the connection between the materials and the artwork occurs on a visual level due to the fact that the visual details raise unexpected issues and unforeseen perspectives. They intertwine with the conceptual work and, accordingly, the analytical direction might become redirected within the process. For example, thanks to my cartoon making and partly inspired by the conception of border aesthetics, I started to ponder the issue of recognition of objects in tandem with an analysis of the abovementioned example of the suitcases. Therefore, I argue that the original combination of the text and the drawings seems to suggest that only by looking at the appearance of the suitcase it is possible to conclude what type of salesperson the suitcase belongs to, and what kinds of objects the suitcase contains.

The cartoon-making process moves back and forth between the research material and the research discussions that arise. The one in this paper is 
based on several discussions of mobility and borders, which regularly involve the issue of defining new vocabularies and approaches. Multimodal analysis, accompanied with art making, could, in turn, provide the founding elements and details for developing these approaches. Also, artistic creation could serve as a vehicle of assessing analytical presumptions and redirecting interpretations, which in turn may help to meet the challenges possibly raised by the detailed and 'impressionistic' orientations seen in multimodal analysis (see Jewitt 2009: 26-27). This paper, however, discusses some of the preliminary notions and conclusions that emerge from taking such a methodological stance. Therefore, one future task is to further ponder these cartoon-bound notions together with the research literature, not only to discuss the challenges that this kind of work involves, but also to identify and develop their further potential as an analytic direction.

\section{ACKNOWLEDGEMENTS}

This paper is based on a presentation given during the CEES 2018 conference, and partly on papers with a similar topic presented at other conferences in 2019 . The overall study on which this article is based is being conducted within the research project The Lost Mitten and Other Stories: Experiences about Borders, Mobilities, and New Neighbour Relations, funded by the Kone Foundation (2018-2020).

\section{NOTES}

1 Formerly, I worked as a visual artist.

2 Various discussions link arts with research, for instance, from anthropological (Schneider \& Wright 2010) or ethnographical (Horst \& Hjorth 2014) positions. The perspective of artistic research is implemented regularly in an arts schools' context (see Kiljunen 2002).

3 All materials originate from the Folklore Archives (KRA) (the Archive Materials on Traditional and Contemporary Culture) at the Finnish Literature Society (SKS). The abbreviation KT refers to the Kansantieto periodical's survey. Following the established practice, the year points to the date when the description was handed over to the archive, and the name to the person who collected and handed the material over to the archive (and not necessarily to the informant). The example texts are translated (reproducing original linguistic styles) by the author. In the first picture, the text reads: "While on the road, and in case the horse freezes because of a ghost, one should hit the road in front of the horse three times crosswise. Then, the ghost should disappear." All figures cropped (and the details in the figure 6 blurred) by the author. 
4 According to Kress and van Leeuwen (2006 [1996]: 177), the "information value" of a representation rests on a view that " $[t]$ he placement of elements ... endows them with the specific informational values attached to the various 'zones' of the image: left and right, top and bottom, center, and margin". The capitalization in Ideal, Real, etc., is used in the original.

$5 \quad$ Kress and van Leeuwen (2006 [1996]: 155) point out that the concept of modality originates from linguistics. However, they also argue that " $[t]$ he concept of modality is equally essential in accounts of visual communication" (ibid.: 156).

6 This is an example taken from a four-page description, which deals also with the transfer of the farm to the next generation. The text says: "Men delivered cargo during the winter, while in the summer they managed their own affairs, harvesting and cutting. In those days, short-handled scythes, as seen in the figure, were used not only for hard, but also for smooth grasses. This kind of scythe bears a resemblance to a sickle used for cutting corn...." (SKS KRA. Jeskanen, Antrei KT 126:24. 1936)

7 The text above the drawings says: "The Russian peddlers had two names: konttimies (sack-man) and harjumies (brush-man). A sack-man sold clothes and possessed a large backpack made of sailcloth. The backpack was equipped with belts and it was so wide that an ordinary roll of cloth fitted in it sideways. They carried these on their backs. The brush-man had a wooden container that was equipped with boxes. He sold knick-knacks.” (SKS KRA. Hoikkala, Gunilla KT 107:26. 1937)

8 The textual plane of borders (see Schimanski 2006: 53-54) is conceivable here in terms of the interaction between the text and the reader, and a textual border appears when the drawing is distinguished from the text by a frame (see Fig. 2). In multimodal terms, framing is an analyzable compositional feature in addition to information value and salience (see Kress \& van Leeuwen 2006 [1996]: 177).

9 In addition, I specified temporal borders, for example, between the old times and the present or between the future and the present. However, I have not considered them in this particular paper as the focus is elsewhere.

10 The text says: "Another poor man built a small cabin. The front door opened straight into the yard, as there was no porch on the house, not even a veranda with a roof. So, he had the whole village as a 'porch'. When the villagers had left something in the yard, they said: 'It is in Juho-Kusti's porch'." (SKS KRA. Pulliainen, Liina KT 257:146. 1948; the name Juho-Kusti has been changed)

11 I used these documents partly as inspiration for making a comic album (see Korolainen 2020). The album is linked to the research; however, this paper deals with other cartoons because the album was not yet published at the time of writing (it was published in February 2020). 


\section{ARCHIVAL SOURCES}

SKS KRA - Folklore Archives of the Finnish Literature Society (archival materials on traditional and contemporary culture)

KT - Kansantieto periodical's survey, 1936-1939 (including the responses received up to 1960) (southern Savonia ( $\left.f^{*}\right)$, northern Karelia (j), southern Karelia (including the Karelian Isthmus) (h), and Ladoga Karelia (i); * is the SKS symbol for a folklore area)

\section{INTERNET SOURCES}

Drawing Research Network. Available at https://www.lboro.ac.uk/research/tracey/drn/, last accessed on 20 April 2020.

OED 2019 = The Oxford English Dictionary. Available at https://www.oed.com/view/ Entry/120494, last accessed on 27 March 2020.

\section{REFERENCES}

Anttonen, Pertti J. 2005. Tradition through Modernity: Postmodernism and the NationState in Folklore Scholarship. Helsinki: SKS.

Barone, Tom \& Eisner, Elliot W. 2012. Arts Based Research. Los Angeles \& London \& New Delhi \& Singapore \& Washington: SAGE Publications.

Brambilla, Chiara 2015. Exploring the Critical Potential of the Borderscapes Concept. Geopolitics, Vol. 20, No. 1, pp. 14-34. http://dx.doi.org/10.1080/14650045.2014. 884561.

Cahnmann-Taylor, Melisa 2008. Arts-Based Research: Histories and New Directions. In: Melisa Cahnmann-Taylor \& Richard Siegesmund (eds.) Arts-Based Research in Education: Foundations for Practice. New York \& London: Routledge, pp. 3-15.

Dell'Agnese, Elena \& Amilhat Szary, Anne-Laure 2015. Borderscapes: From Border Landscapes to Border Aesthetics. Geopolitics, Vol. 20, No. 1, pp. 4-13. http:// dx.doi.org/10.1080/14650045.2015.1014284.

Garner, Steve 2008. Towards a Critical Discourse in Drawing Research. In: Steve Garner (ed.) Writing on Drawing: Essays on Drawing Practice and Research. Bristol: Intellect, pp. 15-26.

Glassie, Henry 1999. Material Culture. Bloomington: Indiana University Press.

Haavio, Martti (ed.) 1936. Kansantieto. Suomalaisen Kirjallisuuden Seuran Kansanrunousarkiston kyselylehti. [Folklore: The Questionnaire of the Folklore Archive at the Finnish Literature Society.] Helsinki: SKS.

Horst, Heather \& Hjorth, Larissa 2014. Visualising Ethnography: Ethnography's Role in Art and Visual Cultures. Visual Studies, Vol. 29, No. 2, pp. 125-127. http:// dx.doi.org/10.1080/1472586X.2014.886862. 
Ingold, Tim 2007. Lines: A Brief History. London: Routledge.

Jaago, Tiiu 2018. Multi-Dimensional Borders in Narration. Folklore: Electronic Journal of Folklore, Vol. 73, pp. 145-160. https://doi.org/10.7592/FEJF2018.73.jaago.

Jewitt, Carey 2009. An Introduction to Multimodality. In: Carey Jewitt (ed.) The Routledge Handbook of Multimodal Analysis. London: Routledge, pp. 14-27.

Jussila, Osmo 2004. Suomen suurruhtinaskunta. 1809-1917. [The Grand Duchy of Finland: 1809-1917.] Helsinki: Werner Söderström Osakeyhtiö.

Kiljunen, Satu 2002. Artistic Research in Fine Arts. In: Satu Kiljunen \& Mika Hannula (eds.) Artistic Research. Helsinki: Academy of Fine Arts, pp. 15-28.

Klein, Barbro 2006. Introduction: Telling, Doing, Experiencing: Folkloristic Perspectives on Narrative Analysis. In: Annikki Kaivola-Bregenhøj \& Barbro Klein \& Ulf Palmenfelt (eds.) Narrating, Doing, Experiencing: Nordic Folkloristic Perspectives. Studia Fennica Folkloristica 16. Helsinki: SKS, pp. 6-28.

Korolainen, Kari 2014. Perinnetieteet ja piirrosten tieto: Piirrosten asema Axel Olai Heikelin ja Elsa Enäjärvi-Haavion tutkimuksissa. [Folklore Studies and Knowledge of Drawings: The Use of Sketches in Axel Olai Heikel's and Elsa EnäjärviHaavio's Studies.] Elore, Vol. 21, No. 2. https://doi.org/10.30666/elore.79153.

Korolainen, Kari 2017. The Handwork of Folkloristic-Ethnological Knowledge: The Viewpoint of Samuli Paulaharju's Drawings. Ethnologia Fennica, Vol. 44, pp. 35-51. https://doi.org/10.23991/ef.v44i0.59693.

Korolainen, Kari 2020. Marjatta \& Ilman Kinna. [Marjatta and Ilman Kinna.] Joensuu: Kirjokansi.

Kress, Gunther 2010. Multimodality: A Social Semiotic Approach to Contemporary Communication. London: Routledge.

Kress, Gunther \& van Leeuwen, Theo 2006 [1996]. Reading Images: The Grammar of Visual Design. London \& New York: Routledge.

Lukkarinen, Ville 2015. Piirtäjän maisema: Paikan kokeminen piirtämällä. [Drawer's Landscape: Experiencing Place by Means of Drawing.] Helsinki: SKS.

Miller, Daniel 2010. Stuff. Cambridge: Polity Press.

Morehouse, Barbara J. 2004. Theoretical Approaches to Border Spaces and Identities. In: Vera Pavlakovich-Kochi \& Barbara J. Morehouse \& Doris Wastl-Walter (eds.) Challenged Borderlands: Transcending Political and Cultural Boundaries. Aldershot: Ashgate, pp. 19-40.

Naukkarinen, Ossi 2006. Liikkumisen kulttuuri. [The Culture of Movement.] In: Ossi Naukkarinen \& Arto Haapala (eds.) Mobiiliestetiikka: Kirjoituksia liikkeen ja liikkumisen kulttuurista. [Mobile Aesthetics: Writings on the Culture of Motion and Movement.] Lahti: Kansainvälisen soveltavan estetiikan instituutti, pp. 12-38.

Noyes, Dorothy 2016. Humble Theory: Folklore's Grasp on Social Life. Bloomington \& Indianapolis: Indiana University Press.

Perera, Suvendrini 2007. A Pacific Zone?: (In)Security, Sovereignty, and Stories of the Pacific Borderscape. In: Prem Kumar Rajaram \& Carl Grundy-Warr (eds.) Borderscapes: Hidden Geographies and Politics at Territory's Edge. Minneapolis: University of Minnesota Press, pp. 201-227. 
Povrzanović Frykman, Maja \& Humbracht, Michael 2013. Making Palpable Connections: Objects in Migrants' Transnational Lives. Ethnologia Scandinavica, Vol. 43, pp. 47-67.

Pöysä, Jyrki 2018. Nationalism(s) and Finnish Folklore Studies - a Narrative View. In: Gábor Gyáni \& Anssi Halmesvirta (eds.) Cultural Nationalism in a FinnishHungarian Historical Context. Budapest: Magyar Tudományos Akadémia, pp. 97-118.

Rajaram, Prem Kumar \& Grundy-Warr, Carl 2007. Introduction. In: Prem Kumar Rajaram \& Carl Grundy-Warr (eds.) Borderscapes: Hidden Geographies and Politics at Territory's Edge. Minneapolis: University of Minnesota Press, pp. ix-xl.

Rosello, Mireille \& Wolfe, Stephen F. 2017. Introduction. In: Johan Schimanski \& Stephen F. Wolfe (eds.) Border Aesthetics: Concepts and Intersections. New York, NY \& Oxford: Berghahn Books, pp. 1-24.

Schimanski, Johan 2006. Crossing and Reading: Notes towards a Theory and a Method. Nordlit: Tidsskrift i Litteratur og Kultur, Vol. 10, No. 1, pp. 41-63. http://dx.doi. org/10.7557/13.1835.

Schneider, Arnd \& Wright, Christopher 2010. Between Art and Anthropology. In: Arnd Schneider \& Christopher Wright (eds.) Between Art and Anthropology: Contemporary Ethnographic Practice. Oxford: Berg, pp. 1-21.

Tilley, Christopher 2001. Ethnography and Material Culture. In: Paul Atkinson \& Amanda Coffey \& Sara Delamont \& John Lofland \& Lyn Lofland (eds.) Handbook of Ethnography. London: SAGE Publications, pp. 258-272.

Urry, John 2008. Moving on the Mobility Turn. In: Weertz Canzler \& Vincent Kaufmann \& Sven Kesselring (eds.) Tracing Mobilities: Towards a Cosmopolitan Perspective. Aldershot: Ashgate, pp. 13-23.

Ursyn, Anna 2008. Digital Drawing, Graphic Storytelling and Visual Journalism. In: Steve Garner (ed.) Writing on Drawing: Essays on Drawing Practice and Research. Bristol: Intellect, pp. 169-179.

Virtanen, Leea \& DuBois, Thomas 2000. Finnish Folklore. Helsinki: SKS \& Seattle: The University of Washington Press.

Wilson, William A. 1985. Kalevala ja Kansallisuusaate. [Folklore and Nationalism in Finland.] Helsinki: Työväen Sivistysliitto.

Yuval-Davies, Nira \& Wemyss, Georgie \& Cassidy, Kathryn 2018. Everyday Bordering, Belonging and the Reorientation of British Immigration Legislation. Sociology, Vol. 52, No. 2, pp. 228-244. http://dx.doi.org/10.1177/0038038517702599.

Kari Korolainen is postdoctoral researcher $(\mathrm{PhD})$ at the Karelian Institute at the University of Eastern Finland. He works in the project The Lost Mitten and Other Stories: Experiences about Borders, Mobilities, and New Neighbour Relations (funded by the Kone Foundation, 2018-2020). His main research areas are folklore and cultural studies, especially from the viewpoint of visual 
and material cultures. Recently, Korolainen has focused also on mobility and border studies, as well as art making (cartoons) along with research. Formerly, Korolainen worked as a visual artist.

kari.korolainen@uef.fi 